\title{
Letting Wood Rot: A Case Study on Local Perceptions of Global Conservation Initiatives (Boumba, Niger)
}

Jocelyn Müller ${ }^{1}$, Iro Dan Guimbo ${ }^{2}$

\author{
Author Addresses: ${ }^{1}$ Tufts University, Biology Department, 163 Packard Ave. Medford, Ma 02155, ${ }^{2}$ Abdou Moumouni \\ University, Niger \\ Jocelyn.g.mueller@gmail.com
}

Received: November $15^{\text {th }} 2010$

Volume 1:40-50

Published: January $21^{\text {st }} 2011$

(C) 2010 Society of Ethnobiology

\begin{abstract}
Although there is a pressing need for conservation in Africa and a push for such actions to be directed by the community, there is still much conflict both in academia and on the ground regarding the success and methods of communitybased conservation. Employing key-informant interviews, focus group discussions and participant observation, we look at how one community has perceived the conservation actions in their village, Boumba, Niger, and the neighbouring national park, Park-W. This study examines local perceptions of the goals, priorities and methods of conservation in Park-W and the Boumba region. We demonstrate that while participants expressed positive alignment with perceived conservation goals, they did not agree with conservation priorities and felt strongly against the methods. Reframing conservation discourse in the terms of sustainable-use or adaptive management may serve to help translate much of the conservation ethic to local realities. We argue that for local conservation to be culturally sustainable, programmers of conservation must engage the community on their own terms, and recognize the value of local perceptions.
\end{abstract}

Key Words: Community-based Conservation, Niger, Parks and People, West Africa

\section{Introduction}

In Africa poaching, illegal grazing, and harvesting in National parks continues to increase even as many national governments in Africa increase their efforts around the parks, (Gibson 2001; Hayes 2006). This has led many observers to argue that protectionist conservation policies, which exclude local communities from the decision-making process, can no longer be justified and sustained in the face of increasing African poverty (Darkoh and Rwomire 2003; Peet and Watts 2004). Instead researchers and practitioners alike seek to connect community development and nature conservation through initiatives such as communitybased conservation, ecotourism, non-timber forest product commercialization, and integrated conservation and develop-ment programs (Gibson and Marks 1995; Pretty and Guijt 1992; Wells and McShane 2004). These methods, which for the purpose of this paper are collectively termed community-based conservation, have become so popular that Berkes (2004) stated in a recent paper that it would be hard to find a conservation program that does not "claim" that it is community-based.

However, the "successes" of such communitybased conservation programs have been limited and conflicted (Berkes 2004; du Toit et al. 2004; Oates 1999). In a study of 93 parks or protected areas throughout the tropics, parks were shown to be better than "alternative arrangements" at protecting biodiversity (Bruner et al. 2001). However, Hayes (2006) refuted this study both methodologically and also through her own findings, which demonstrated no significant difference in the condition of forest areas with strong legal protections compared to those managed by local users. Despite these conflicting results regarding conservation benefits, many have argued that these programs have also shown few social improvements for the target constituents (Ndaskoi 2003; Rutten 2002) and may in fact be a tool for legitimizing further exploitation of the poor (Brett 2003; Hayward et al. 2004).

This has led some researchers to argue that conservation and development goals should not be linked, as neither's aims are served well through such joint programs (Oates 1999; Rutten 2002). In a response article, Redford and Sanderson (2000) argued that such linked programs represent an important form of conservation, but should not be considered conservation in its truest sense. They posit that holding community-based conservation to the same standards as "people-free" parks turns advocates of these different programs into competitors rather than allies. While their position is well-reasoned, it does not help to fix some of the chronic problems with 'fences and 
fines' methods of conservation, especially in Africa (Adams and McShane 1992).

Instead others have argued that these shortcomings are evidence for the need to critically evaluate community-based conservation efforts for their ability to live up to promises of participation, biodiversity enhancement, and social benefits (Hulme and Murphree 1999). Following this call, research has emerged that focuses on the methods and context of participation (Hickey and Mohan 2005; Kesby 2005; Quaghebeur et al. 2004; Zanetell and Knuth 2002). Several studies focus on the assumptions, beliefs, and attitudes of all stakeholders that limit effective joint action (Kideghesho et al. 2007; Sekhar 2003; Weladji et al. 2003). Many anthropological and political studies of participatory research in general demonstrate that weak forms of participation yield little power and few benefits to the community (Hayward et al. 2004; Hickey and Mohan 2005). Other studies indicate that problems in the definition of community (Selfa and Endter-Wada 2008), or the design of community programs can limit engagement and inclusion of local knowledge and perspectives (Berkes 2004; Goldman 2003; Songorwa 1999; Turner 1999). Many studies have focused on well-established programs, such as CAMPFIRE in Zimbabwe and ADMADE in Zambia, which had already been declared successes or failures. This paper follows this stream of literature seeking to examine the limitations, challenges, and assumptions underlying community-based conservation programs, but within the context of a program still in an early stage of transitioning from park-based conservation to community-based conservation.

We focus this paper on Boumba, Niger, a West African community located on the edge of a tri-national biosphere reserve. Although never forcibly displaced, the Boumba community has been historically excluded from the park, but recently co-opted in new park policy which promotes community-based conservation. This paper explores attitudes and perceptions of local residents regarding the fundamental goals, priorities and methods of conservation. We aim to identify potential barriers to community-based conservation, incorporating local knowledge and needs at this early stage in order to serve as a model for other programs with continual monitoring of community-based conservation goals. This case study of the community in Boumba, Niger, on the edge of a national park, examines local perceptions of the priorities, goals, and methods of internationally-derived, but locally executed conservation initiatives. We explore how these perceptions can limit the success of community-based conservation initiatives.

\section{Study Area}

Park "W," named after the W-shaped form in the Niger River, is a trans-frontier park including areas in Niger, Burkina Faso, and Benin. It has recently been named a biosphere reserve and recognized globally as a world heritage site (Turner 1999). The park's geography and hydrology make it an extremely valuable region to local people and wildlife. Boumba is a village located right on the edge of Park W, where the Niger River exits the park to continue along the Benin-Niger border in a southeast direction. This setting has attracted a number of groups of people to the region. Of the extant groups, the Zarma have the longest history in the village and make up the majority of the population. Additionally, the village is comprised of minorities of Hausa fishermen, Fulani herders, and Mauri hunters.

Most recently, this village's geography and historical importance have attracted the interest of several government and non-governmental organizations seeking to either protect or exploit the natural and social resources of the region. Established in the early $1^{\text {th }}$ century as a game reserve for the French colonialists, the park has changed its governance, purpose and borders several times since its conception. The most marked change came in 1954 as the game reserve was redefined as a national park. The 1954 change from reserve to park had several ramifications, the most dramatic perhaps being the forced relocation of all people living within the park borders. This relocation program did not displace the village Boumba, which lies just outside the park, but is still marked vividly in the local memory and history of the region. Residents describe village burnings and taking in of refugees. Boumba became one of the sites of relocation, as people searched for new places to establish themselves and their livelihoods. For most people interviewed, 1954 marked the beginning of the park. As a game reserve, management focused on minimizing hunting and did not threaten the livelihood of the majority of Zarma farmers. After the resettlement, park access became much more restricted, use of park resources more limited, and the whole discourse of conservation changed.

After this event, Boumba became a government forestry post, park enforcement became stricter, and management policies were enacted in response to changes in global conservation narratives. Fire became a management tool in the 1930s through a French decree. This policy permitted an annual state-led, early 
burn program that resembled early community-led "bush" burnings, while maintaining the ban on all community initiated fires as a threat to national forests (Laris and Wardell 2006). Fires continue to be banned in non-park lands but were set within the park for management purposes. Then in the 1990s the global interest in community-based conservation and community run ecotourism finally made its way to Boumba in the form of a European Union-funded conservation organization. This led to the establishment of a community-owned camp-ground and the development of several non-timber forest product commercialization projects, the largest being a women's shea butter project (Boulet et al. 2004). Although discussion of participatory approaches began in the late 90 s, these efforts were first felt through the launching of the ECOPAS (Ecosystèmes Protégés en Afrique Sahélienne) program in 2001. This paper explores how the current conservation initiatives are understood and perceived by the local community in Boumba, Niger at this stage.

\section{Methods}

Participatory fieldwork conducted from July 2005 until August 2007, employed semi-structured interviews, participant observation, group discussions, and community mapping to explore how local knowledge can inform conservation. However, through engagement with the community, disconnects between local perceptions of conservation actions and stated conservation objectives became apparent. Correspondingly, we did a second analysis to better understand local perceptions of conservation.

Over the course of our fieldwork, the first author conducted key-informant interviews with 17 men and 20 women, ranging from age 30 to 100 . The second author conducted interviews with 16 men, 14 women and 9 youths. Although generally key informant interviews are conducted with a single participant present, in this study the interviews were often conducted in the presence of other family members or neighbours (37 households). The analysis, however, treated the results as coming from a single respondent, because the structure of the question guide was intended for a sole respondent and other responses were channelled through the named interviewee. Interviews were conducted in Zarma or in Hausa. If needed, a local translator was employed to go between the native language of the participant and language spoken by the researcher.

We conducted eight focus group discussions, which in contrast to the key informant interviews were intended to draw out a variety of perspectives. The focus groups included two discussions with an open invite to local women, two with an open invitation to local men, two that met with local fisherman, one with local hunters, and one with conservation agents. These groups ranged from five to twenty adult participants. Because the region contains a Zarma majority, the group discussions were conducted in Zarma.

In addition, these data were supplemented by information gathered from informal discussions, community-guided forest walks, a combined total of over 1000 hours of participant observation in Boumba, and previous engagement in the region by the authors. Discussions that took place in the context of participatory ecological field work also entered into the analysis. As these interviews were conducted in the course of vascular plant surveys, it was not possible to tape the discussions. Thus these discussions were not part of the texts used for content analysis. Instead notes and observations from those surveys were relied upon to complement and interpret the results of the interviews.

The first author conducted all of her formal interviews and recorded them digitally. The recordings were translated, transcribed, and imported into NVivo 7 qualitative data analysis software for coding and content analysis. The second author used his notes from his interviews to conduct his analysis on the local perceptions of conservation. We looked for phrases and comments regarding the participants' perceptions of the goals, priorities, or methods of conservation.

This study was approved by the ministry of higher education and research in Niger and the institutional review board at Tufts University. Permission was given from local, regional, and state level authorities to work in the community. All participants in formal interviews or discussion groups gave oral consent to participate and to be taped.

\section{Results \& Discussion}

Goals of Conservation-In the interviews and discussions with residents of Boumba regarding conservation goals (Figure 1) the most common concept or theme of the discussion is tree protection. Trees or forest came up in each formal interview and was a consistently recurring topic in discussions. In fact, linguistically, it is difficult in Zarma or Hausa to talk about plant or habitat conservation at all outside of the context of trees. The Zarma word for trees is often translated as 'vegetation' and conservation agents are called 'forest' guards. Even in the discourse of wildlife preservation, deforestation is considered one of the greatest threats. When asked 


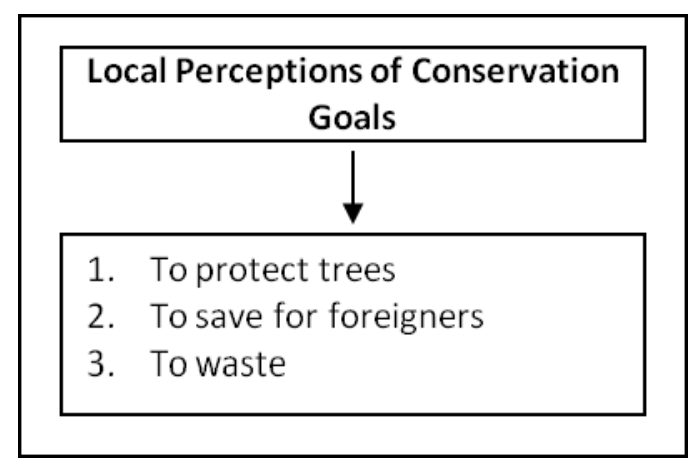

\section{Figure 1. A summary of common themes that emerged during discussions of the poals of conservation with residents of Boumba, Niger.}

about the lack of elephants or wild game, one participant responded, "The trees [forests] are all old and dying, soon there will be no trees for us and for the wild animals." Some participants attributed the decline in tree populations to human causes, others to climatic changes; others did not know why the trees were dying. However everyone interviewed talked of correcting the problem of tree die-off as a clear conservation goal.

This association between conservation and trees has historical relevance. Early colonial interpretations of the landscape argued that the Sahelian savannah represented a degraded forest, derived from human misuse of the land (Fairhead and Leach 1996; Laris and Wardell 2006; Leach and Fairhead 2000). Although this interpretation of the landscape has been challenged, its influence is still very present in the national discourse of conservation and the environment (Fairhead and Leach 1994).

While trees play important keystone functions in the ecosystem (Dean et al. 1999), most of the large wildlife (elephants, water buffalo, gazelles, roan antelope) are grassland species. Still the fire policy is implemented to promote trees, not grasses (Sprugel 1991), and one of the conservation agents stated that his job is to protect the "last remnants of the forest." This emphasis on trees and forest, rather than grasses and savannah, was then reflected in the community discussions on conservation.

To foster a discussion with local residents on preserving grasses, key conservation terms such as environment, park, and protection had to be omitted. There are many perennial grasses that are traditionally protected and valued as highly as some trees, but discussions of these resources were nearly absent from the focus group and key informant discussions regarding the goals of conservation. It is important to note, that though all of the participants had animals, there were no pastoralists among the interviewees. It is possible to interpret part of this lack of discussion on grasses to reflect also the lack of participation on the part of pastoralist groups.

After trees and forests the next most common theme that appeared in community discussions of the goals of conservation related to the role of foreigners. While only five participants stated that the goal of conservation is to attract and please tourists and foreigners, specifically European and Euro-Americans, indirect references to this concept were common in discussions or in interviews. For example, one respondent kept referring to Park W as "your [the American's] park; the Anasaras park." Anasara is a Zarma term applied to western foreigners. The term, however, is not applied to foreign Arabs and only haphazardly applied to East Asians, two groups that play significant roles in conservation at a national level, but rarely in Boumba itself. Therefore, discussions of the park in the context of the term Anasara, indicate local perceptions are being shaped primarily by local experience rather than by national or global conservation perspectives.

Furthermore, since 2003 there have been major initiatives within Boumba and Park $\mathrm{W}$ more generally to promote community-based conservation, but still the discourse is about conservation for foreigners, Anasaras. The most tangible result of the new conservation programs in the community's eyes are the new community-owned campground and women's shea butter co-operative, both intended to provide more direct benefits from the conservation efforts to the community. However, despite outward claims of large profits (Boulet et al. 2004), members of the campground board report that the campground itself has produced little revenue for the community and is not covering its costs; so there were only two references made in the interviews between tourism and profit for the community. Instead, discussions focused on either the non-monetary benefits of having a campground that brings Anasaras, or bitterly relating how entrance fees for the park are priced out of range for local inhabitants and that the facilities designed to attract foreign visitors bring little benefit to the community.

This concept that conservation of natural resources equates to designation for viewing by foreigners leads into the third most commonly discussed goal-related theme: conservation is wasteful. This perception was such a repetitive theme in interviews and informal discussions that it seemed local residents interpreted 
the goal of conservation as the promotion of wastefulness. Residents can see how valuable plants are not harvested, but are burned or simply left to rot every year in the park. The title of this paper, "Letting Wood Rot," comes from a statement a woman made as the research team passed a fallen branch. It speaks volumes toward the cultural divide between residents of Boumba and conservation programmers. The phrase translates well into each language but the intent and value behind the statement differs. Western research lists many benefits of wood left to rot in nutrient cycles, habitat structure, and ecosystem services, whereas local views voiced by this woman list primarily how this wastes local fuel and timber. It seems if community-based conservation is to continue, these background values must be made clear and both parties may have to readjust their thoughts on "letting wood rot" in order to find consensus.

This perception of wastefulness was reinforced in the vascular plant surveys where discussions often revolved around the economic, nutritional, and medicinal values of the habitat that were not being tapped. The broad concept of wastefulness came up in about one third of the interviews, often with women. Most of the products mentioned as being wasted were non-timber forest products: leaves, herbs, grasses, and fruits. Sometimes this idea seemed to be exaggerated to a point approaching fantasy. One participant stated regarding a favorite pot herb: "I have heard in the park there are fields and fields of foy juto (Ceratotheca sesamoides Endl.) that are just left to wilt each year. We are hungry and the park has food-fields and fields of it." This statement, while not false, does overestimate the true abundance of this herb in the park and seems to reflect how limited local engagement in the park distorts local perceptions.

In contrast U.S. parks are primarily patronized by nearby residents. Ongoing studies conducted by the University of Idaho and the U.S. National Park Service show that a majority of visitors of most parks come from the states that contain or border National Parks. To give one example, United States visitors comprised 91\% of total visitors to Yosemite National Park, with $89 \%$ of the visitors coming from the home state California (Le et al. 2008). Although few western parks are set up to provide direct revenue to the region (Hjerpe and Kim 2007) they are considered a source of employment and benefit communities in education and recreation services (Brody and Tomkiewicz 2002; Taylor 2006). When the discourse of western conservation talks about saving for our children or our future, Boumba community members talk about conservation for the sake of someone else's children. Even in the context of community-based conservation initiatives, community members talk little about conservation goals of improving the lives, livelihoods, or health of local residents, but rather to save things for the Anasaras to look at. In the words of the former camping ground guardian, "These [tsetse flies] are the profits the park gives us. Your park, you come and look and we swat flies." Despite being an employee of the campground, he not only thought of the park in terms of foreigners, but also thought of it negatively.

Principles of Conservation-Although the discussions of goals and priorities are linked, it was primarily in discussions of how conservation aims are prioritized that residents talked explicitly about the divide between their own and outsiders' perceptions and values (Figure

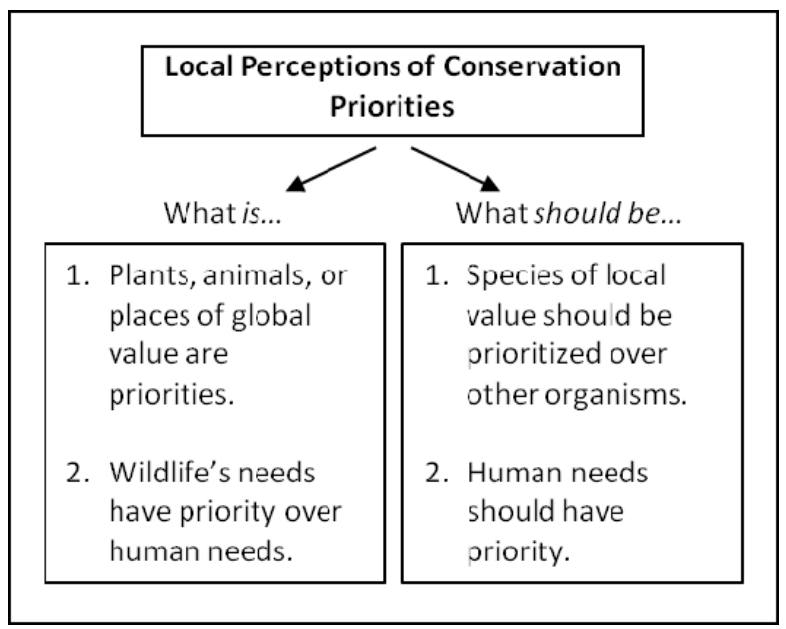

Figure 2. A summary of common themes that emerged during discussions of the priorities of consevation with residents of Boumba, Nigcr. In the discussions of the priorities, participants often framed the responses in the form of what is and what should be.

2). In discussions of how conservation goals are prioritized discourse split into what is and what should be. There was not clear opposition to any perceived goals, even when responses seemed negative. Over two-thirds of interview participants expressed some level of understanding for the reasoning behind conservation policy and implementation, and many expressed agreement or alignment. However, in discussions of priorities, not a single participant expressed complete satisfaction with the priorities of conservation, even among the conservation agents. Instead participants felt frustration in the way conservation goals were prioritized and many would express strong opinions as to how things should be prioritized. 
When the discourse turned to how things should be prioritized, it was clear that not all trees and not all fish were the same. Community members felt species should have high conservation priority if they had multiple uses or if they drove a high price at the market. In pairwise ranking exercises this was clearly demonstrated as the groups compared a number of valuable trees to one another. For some tree pairs there was no discussion; one plant was a clear winner over the other. In other cases, participants listed the number of uses each tree has (medicine, food, shade, craft, timber etc.) in order to decide. Then, if the number of uses came out even, tie breaking depended on the gender of the participants. Male participants would turn to the market price of the most commonly sold product. If both were commonly sold for wood, the higher priced wood would win out. For women, the tie-breaking question asked if anything from the tree could be eaten and, if so, how full the food from the tree would make them.

In the context of what $i$, participants commonly referred to how conservation agents prioritize the conservation of certain trees, fish, and the park interior and more importantly prioritized enforcement of restrictions concerning development of benefit sharing. These priorities as described by local residents reflect many local realities. The most stringently regulated activities are wood harvest, fishing, and park access. These are the activities participants will seek permission for from the forestry guards-activities that generally require official permits and are the cause of conflict, penalties, and corruption. Although in discussion of conservation priorities participants did not distinguish certain species of fish there were several species of trees that were mentioned as having current conservation priority. The ronier palm (Borassus aethiopum Mart.), shea butter tree (Vitellaria paradoxa C.F.Gaertn.), and gum Arabic tree (Faidherbia albida (Delile) A.Chev.) were discussed as being focal points of conservation efforts. There were several other trees that were mentioned as having stringent enforcement of wood harvest, these were not seen as having large management programs, so this discussion focuses on the top three trees, as these also highlight how the perceived priorities did not match the desired conservation priorities of community members.

At first glance it does not seem like these perceptions about values would lead to differences in priorities between local residents and western conservationists, as many of the state or NGO-run programs look at those same criteria in developing linked conservation and development programs. The difference is that such program criteria are not measured at a local scale. For example, F. albida is promoted throughout Niger for its soil enriching properties, agro-forestry benefits, and economic potential as a common ingredient in soft drinks and candies. In discussions with Boumba residents, however, this species was ranked very low, as the soil enriching benefits did not overcome the increased grain losses due to nesting birds, and the locally high water table prohibits the tree from producing gum. Nevertheless, in participatory conservation actions, farmland was donated to create gum arabic plantations, and men and women from Boumba worked to tend nurseries and plant seedlings, demonstrating the overall support for the goals of conservation. However, in discussions with our research team, they expressed their frustration that so much time and effort was spent in planting this "useless" tree, when other valuable trees are hard to find and much more desired. Species such as Ficus sur Forssk., Crateva adansonii DC. subsp. adansonii, or Kigelia africana (Lam.) Benth. were all mentioned as trees which are hard to find in the surrounding area and should be of high conservation priority because of their medicinal or nutritional importance. Even trees such as the Baobab (Adansonia digitata L.) and the important fibre palm (Hyphaene thebaica (L.) Mart.) which were not seen as particularly rare, but were ranked of such high importance that many participants questioned the lack of conservation efforts directed towards these species.

The way that human's versus nature's needs are prioritized was another commonly discussed "what is" or "what should be" juxtaposition in local understandings of conservation. Over $60 \%$ of the interview participants expressed ideas that indicated that human needs should come before nature's needs in conservation goals, but they felt currently human needs were second priority. One conservation agent argued that on the Burkina side of the park they allowed culling of herds:"Here [in Niger] " he said "people need meat, but they [the government at large] won't let us hunt, even alongside a forestry agent... currently it is only my job that prevents me from hunting."

The human-nature tradeoff is a sensitive issue that may be what ultimately fuels debates, such as were expressed in the exchange between Schwartzman and colleagues (2000), Redford and Sanderson (2000) and Terborgh (2000). We do not seek to take a side in this debate, however, in the context of a program that is attempting to switch the focus from people-free parks to community-based conservation, it is important to be aware of pervasive attitudes and challenges. Further, because the issue of people in parks is sensitive, it is 
important to recognize how individuals perceive human needs. In other regions this same argument has been used to open parks to commercial logging (Groom et al. 2006) and to destroy natural habitat. Therefore, many conservationists find a conservation program where human needs are ranked over nature's as inherently contradictive (Oates 1999; Sanderson and Redford 2003).

In Africa, however, we must also recognize the history of the people-free parks, where stated conservation goals were used to cover exploitive, racist policies or make them more palatable (Hughes 2007). Given this politically charged context, it is important to go beyond simply human needs versus wildlife needs to understand underlying perceptions and values. In this study, most respondents were referring to the ability to harvest specific natural resources. To quote one informant, "People are hungry here and there are bushes that could feed us, if we were allowed to go and harvest leaves."

Another participant, when asked about the importance of grasses responded, "We need grasses to build our houses and feed our animals, and the government is burning them over there [in the park] every year."

So for many participants a step toward prioritizing the needs of local residents would be to allow some access to the natural resources and direct benefits of their use. In an earlier study of the Park W complex, when participatory methods of conservation were still being explored in Niger, Turner (1999) argued that the poor infrastructure and limited revenue earning potential of the park required more direct incentives and benefit sharing through local people's use of natural resources.

Methods of Conservation - This brings us to the third set of themes discussed under the general category, the methods of conservation (Figure 3). When participants were asked to comment on the methods of conservation three main themes emerged: corruption, restriction, and intimidation. These perceptions vividly reflect the oppressive history of conservation methods and the disparities between the local community and conservation agents. Interestingly if something was considered to be off-limits or inaccessible because of restrictive conservation laws, then from the perspective of the participants the conservation priority is lowered. A clear example of how conservation actions can diminish the local conservation priority is with wildlife; due to the government ban on large game hunting most villagers have little to no use for wildlife and also

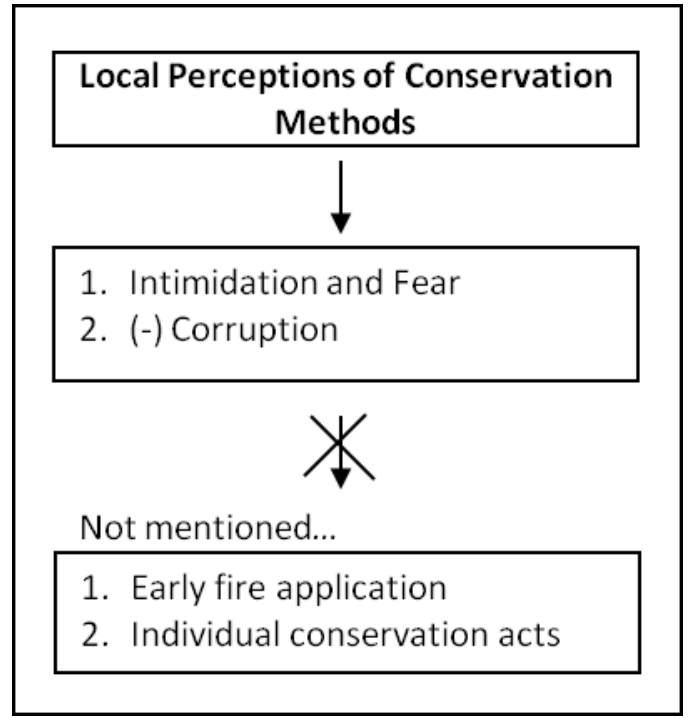

\section{Figure 3. A summary of common themes that emerped and were absent during discussions of the methods of conserwation with residents of Boumba, Niger.}

little incentive to conserve or manage their populations. This opinion has changed recently in discussions with villagers since the initial study in 2005-2007. In the winter of 2007, elephants were frequently seen grazing on the banks opposite Boumba village. Community members did not cross the river to enter Boumba fields and raid crops as they are known to do in other parts of Africa (Gadd 2005), although stories of that happening in the Benin village across the Niger river were heard of in the Boumba area. But this frequent viewing became a great point of discussion in town, and many people expressed pride and agreement with conservation efforts. Although this represents a change in opinion as one form of wildlife became more visible, the general view of wildlife (visible elephants aside) reinforces the idea that conservation actions that limit local engagement with resources can negatively alter attitudes of conservation even in the absence of direct conflict.

Going beyond these negative aspects of local perceptions of conservation methods, it seems there are key themes absent from discussions that seem to better illuminate potential challenges to communitybased conservation. There were no references to fire being a method of conservation, even though fire is the forestry agents' major form of management within the park and village residents used fire historically to promote soil fertility and grasses. Nor was there mention of community involvement in larger conservation efforts, even though for at least the past two years there have been efforts by various 
development organizations to lead community-based conservation initiatives and to promote ecotourism. Participants did not mention individual forms of conservation, or what they do to promote biodiversity or to preserve important plants on their own land. The majority of participants saw conservation not as actionbased, but as preventative, such as not cutting down trees or not harvesting wildlife. Further, they felt inaction was maintained through laws, restrictions that were enforced through high fines and threats to life and livelihood. This control aspect of conservation is then mitigated through the "bargaining" process of corruption. Thus, from a local perspective, conservation occurs through fear and intimidation and is made bearable through corruption and undermined by ignorance.

Our observations within the village supported the perception of this claim, but they did not support the reality of the claim. In the course of our stay in the region, we documented many examples of local residents purposefully saving valuable trees in their fields, planting rare trees and shrubs in their home sites, and tailoring their harvesting methods to promote regrowth. Even local fisherman recognized that the ideal of 'conservation undertaken by all' is undermined by corruption and poverty. This group traditionally had spiritual leaders who controlled fishing practices and regulated fish harvests, but their positions have been replaced by local conservation agents. However, in discussion with local residents, conservation was initially and predominately associated with the government and only when the conversation would digress from the vocabulary of conservation would people talk about traditional methods of caring for the habitat, protecting species from overuse, or preventing land degradation. For example, one participant when asked directly if there were any trees that the community protected said, "No, we cut down trees. It is the forestry agent who protects trees." Later in the interview we returned to this topic through talking about a traditional belief that powerful spirits reside in or under large trees. That same participant talked about how certain trees contained spirits and could not be cut down without spiritual retribution and plainly stated that "these trees no one cuts down, even if the forestry agent were not there." This local belief in spirits protects many of the large seed trees in the area, yet still the "job" of protecting trees is attributed to the forestry agents. Respondents discussed actions that most western ecologists would agree are beneficial to forest health, such as selective harvest of firewood, protecting seed trees, and farming around seedlings, but none of the respondents listed these activities as ways in which they help the environment. Instead these actions would be discussed when voicing traditional beliefs describing farming practices or explaining collecting methods.

\section{Conclusion}

The major themes that emerged during this study can be tied together through a reflection on the role of consumptive use in conservation. The actions of community members demonstrated that many individuals supported conservation and management of useful species, but did not understand the efforts of "fences and fines" conservation. This was perhaps highlighted best in the binary discussions of conservation priorities (Box 2), and underlined by the presence of negative views toward conservation goals and methods. Although in global discourse of conservation, sustainable management plays a large role in the conservation of economically valuable species, this part of the global conservation discourse was not represented in local residents' perceptions of conservation. Despite recent attempts to provide community members with direct benefits from the park and to implement management programs for valuable species such as the ronier palm and shea butter tree, the enforcement of non-consumptive conservation is still the major paradigm. This is problematic both for the functioning of the community-based aspects of the program and for conservation initiatives in the region. Previous studies have shown that negative attitudes toward conservation can affect the relationship between the park and local populations and undermine conservation efforts (Kideghesho et al. 2007; Simelane et al. 2006). In our study community members expressed values and priorities different from those they observed in conservation actions. Such conflicting value systems raise questions as to the expected success of community-based conservation actions.

For community-based programs, the discourse of conservation must hold consumptive use as equal to non-consumptive use through promotion of sustainable management of locally valued species, as local uses tend to have more direct benefits to the participants. As Kaimowitz and Sheil (2007) describe, we have to start saving biodiversity for the poor, who form essential elements of daily life. A 2003 (Bauer) study based in Cameroon, demonstrated that access to natural resources, or more generally consumptive use, can promote positive attitudes toward conservation as a whole. Holmes (2003) demonstrated that conservation success is partially dependent on the outreach efforts of the conservation programs. While this is true, we also have to recognize what Turner (1999) warned of, an 
educative participation that leaves no room for active engagement. Many of the frustrations expressed with the Boumba community could be addressed in simple changes to conservation priorities without much difficulty, but the key is to start from the bottom-up in order to incorporate these local realities and priorities.

Finally, although this paper argues that a shift in conservation policies from non-consumptive use to consumptive use may address some of the underlying social barriers and increase cultural sustainability (such as long term success of community-based conservation), this paper does not look at the question of ecological sustainability (long term conservation of biological and earth systems). This question is outside the scope of this analysis, but researchers in socioecological resilience argue that ecological sustainability cannot be achieved in the absence of cultural sustainability (Berkes et al. 1998). However, the question remains as to whether a conservation program based on consumptive use is ecologically sustainable. Timko and Satterfield (2008) developed a set of criteria and indicators for evaluating both social and ecological methods. Future studies need to follow this lead and look directly at how true community participation affects the ecological sustainability of conservation. As Park W, like many other African parks, was used as pastureland and farmland as recently as 1950, one might argue that some of the habitat we are aiming to protect is even a result of past consumptive and sustained use.

\section{Acknowledgements}

We thank Dr. Pearl Robinson, Dr. Ayron Strauch and Prof. Astier Almedom who reviewed earlier versions of this paper. We thank all the residents of Boumba and Lt. Abdoulaye Soumana. We thank Mlle. Haouaou Noma and Prof. Mahamane Saadou. This research was funded by the Anne S. Chatham Fellowship (Garden Club of America), Tufts Institute of the Environment, the Switzer Foundation, Graduate Women in Science, and Tufts Graduate School. Dr. Müller was funded by a National Science Foundation graduate research fellowship. A preliminary version of this paper entitled: Letting Wood Rot: the role of consumptive use in conservation-Boumba, Niger was presented at the 2007 Meeting of the Society for Applied Anthropology.

\section{References Cited}

Adams, Jonathan and Thomas O. McShane. 1992. The Myth of Wild Africa: Conservation without Illusion. WW

Norton \& Company, New York.

Bauer, Hans. 200. Local Perceptions of Waza National Park, Northern Cameroon. Environmental Conservation 30:175-181.

Berkes, Fikret. 2004. Rethinking Community-Based Conservation. Conservation Biology 18:621-630.

Berkes, Fikret, Carl Folke, and Johan Colding. 1998. Linking Social and Ecological Systems: Management Practices and Social Mechanisms for Building Resilience. Cambridge University Press, New York.

Boulet, H., C. Vermeulen, A.S. Aladji-Boni, I. Niandou, A. El-Hadj, K. Konate, C. Paolini, O. Novelli, and D. Dulieu. 2004. Regional Strategy for the Management of Hunting Activities around the W Park (Benin, Burkina Faso, Niger). Game \& Wildlife Science 21:663-673.

Brett, E.A. 2003. Participation and Accountability in Development Management. The Journal of Development Studies 40:1-29.

Brody, Michael, and Warren Tomkiewicz. 2002. Park Visitors' Understandings, Values and Beliefs Related to Their Experience at Midway Geyser Basin, Yellowstone National Park, USA. International Journal of Science Education 24:1119-1141.

Bruner, Aaron G., Raymond E. Gullison, Richard E. Rice, and Gustavo A.B. Da Fonseca. 2001. Effectiveness of Parks in Protecting Tropical Biodiversity. Science 291:125-128.

Darkoh, M.B. Kwesi, and Apollo Rwomire, eds. 2003. Human Impact on Environment and Sustainable Development in Africa. Ashgate, Burlington, Vt.

Dean, W.R., S. J. Milton, and F. Jeltsch. 1999. Large Trees, Fertile Islands, and Birds in Arid Savanna. Journal of Arid Environments 41:61-78.

du Toit, Johan T., Brian H. Walker, and Bruce M. Campbell. 2004. Conserving Tropical Nature: Current Challenges for Ecologists. Trends in Ecology \& Evolution 19:12-17. 
Fairhead, James and Melissa Leach. 1994. Contested Forests: Modern Conservation and Historical Land Use in Guinea's Ziama Reserve. African Affairs 93:481-512.

Fairhead, James and Melissa Leach. 1996. Misreading the African Landscape:Society and Ecology in a Forest-Savanna Mosaic. Cambridge University Press, Cambridge.

Gadd, Michelle E. 2005. Conservation Outside of Parks: Attitudes of Local People in Laikipia, Kenya. Environmental Conservation 32:50-63.

Gibson, Clark C. 2001. Politicians and Poachers. Africa 71:723-724.

Gibson, Clark C. and Stuart A. Marks. 1995. Transforming Rural Hunters into Conservationists: An Assessment of Community-Based Wildlife Management Programs in Africa. World Development 23:941-957.

Goldman, Mara. 2003. Partitioned Nature, Privileged Knowledge: Community-Based Conservation in Tanzania. Development and Change 34:833-862.

Groom, Martha J., C. Ronald Carroll, and Gary K. Meffe. 2006. Principles of Conservation Biology. Sinauer Associates, Sunderland, MA.

Hayes, Tanya M. 2006. Parks, People, and Forest Protection: An Institutional Assessment of the Effectiveness of Protected Areas. World Development 34:2064-2075.

Hayward, Chris, Lyn Simpson, and Leanne Wood. 2004. Still Left Out in the Cold: Problematising Participatory Research and Development. Sociologia Ruralis 44:95-108.

Hickey, Sam and Giles Mohan. 2005. Relocating Participation within a Radical Politics of Development. Development and Change 36:237-262.

Hjerpe, Evan E. and Yeon-Su Kim. 2007. Regional Economic Impacts of Grand Canyon River Runners. Journal of Environmental Management 85:137-149.

Holmes, Christopher M. 2003. The Influence of Protected Area Outreach on Conservation Attitudes and Resource Use Patterns: A Case Study from Western Tanzania. Oryx 37:305-315.
Hughes, Lotte. 2007. Rough Time in Paradise: Claims, Blames and Memory Making Around Some Protected Areas in Kenya. Conservation and Society 5:307.

Hulme, David and Marshall Murphree. 1999. Communities, Wildlife and the "New Conservation" in Africa. Journal of International Development 11:277-285.

Kaimowitz, D. and D. Sheil. 2007. Conserving What and for Whom? Why Conservation Should Help Meet Basic Human Needs in the Tropics. Biotropica 39:567574.

Kesby, Mike. 2005. Retheorizing Empowermentthrough-Participation as a Performance in Space: Beyond Tyranny to Transformation. Signs 30:20372065.

Kideghesho, Jafari R., Eivin Røskaft, and Bjørn P. Kaltenborn. 2007. Factors Influencing Conservation Attitudes of Local People in Western Serengeti, Tanzania. Biodiversity and Conservation 16:2213-2230.

Laris, Paul and David Andrew Wardell. 2006. Good, Bad or 'Necessary Evil'? Reinterpreting the Colonial Burning Experiments in the Savanna Landscapes of West Africa. Geographical Joumal 172:271-290.

Le, Yen, Eleonora Papadogiannaki, Nancy Holmes, and Steven J. Hollenhorst. 2008. Yosemite National Park Visitor Study. University of Idaho, Park Studies Unit, Moscow.

Leach, Melissa and James Fairhead. 2000. Challenging Neo-Malthusian Deforestation Analyses in West Africa's Dynamic Forest Landscapes. Population and Development Review 26:17-43.

Ndaskoi, Navaya ole. 2003. Tanzania: the Maasai Predicament. New African June:44-46.

Oates, John F. 1999. Myth and Reality in the Rain Forest: How Conservation Strategies Are Failing in West Africa: University of California Press

Peet, Richard and Michael Watts. 2004. Liberation Ecologies: Environment, Development, Social Movements. Routledge, London.

Pretty, Jules N. and Irene Guijt. 1992. Primary Environmental Care: An Alternative Paradigm for 
Development Assistance. Environment \& Urbanization 4:22-36.

Quaghebeur, Kerlijn, Jan Masschelein, and Hoai Huong Nguyen. 2004. Paradox of Participation: Giving or Taking Part? Journal of Community \& Applied Social Psychology 14:154-165.

Redford, Kent H. and Steven E. Sanderson. 2000. Extracting Humans from Nature. Conservation Biology 14:1362-1364.

Rutten, Marcel M. 2002. Parks Beyond Parks: Genuine Community-Based Eildlife Eco-Tourism or Just Another Loss of Land for Maasai Pastoralists in Kenya? International Institute for Environment and Development, Drylands Programme Issue Paper 111:1-27.

Sanderson, Steven E. and Kent H. Redford. 2003. Contested Relationships Between Biodiversity Conservation and Poverty Alleviation. Oryx 37:389-390.

Schwartzman, Stephan, Adriana Moreira, and Daniel Nepstad. 2000. Rethinking Tropical Forest Conservation: Perils in Parks. Conservation Biology 14:1351-1357.

Sekhar, Nagothu Udaya. 2003. Local People's Attitudes Towards Conservation and Wildlife Tourism around Sariska Tiger Reserve, India. Journal of Environmental Management 69:339-347.

Selfa, Theresa and Joanna Endter-Wada. 2008. The Politics of Community-Based Conservation in Natural Resource Management: A Focus for International Comparative Analysis. Environment and Planning 40:948965.

Simelane, T., G.I.H Kerley, and M.H. Knight. 2006. Reflections on the Relationships Between Communities and Conservation Areas of South Africa: The Case of Five South African National Parks. Koedoe -African Protected Area Conservation and Science 49:85-102.

Songorwa, Alexander N. 1999. Community-Based Wildlife Management (CWM) in Tanzania: Are the Communities Interested? World Development 27:20612079 .

Sprugel, Douglas G. 1991. Disturbance, Equilibrium, and Environmental Variability: What is "Natural"
Vegetation in a Changing Environment? Biological Conservation 58:1-18.

Taylor, Edward W. 2006. Making Meaning of Local Nonformal Education: Practitioner's Perspective. Adult Education Quarterly 56:291-307.

Terborgh, John. 2000. The Fate of Tropical Forests: A Matter of Stewardship. Conservation Biology 14:13581361.

Timko, Joleen and Terre Satterfield. 2008. Criteria and Indicators for Evaluating Social Equity and Ecological Integrity in National Parks and Protected Areas.

Natural Areas Journal 28:307-319.

Turner, M.D. 1999. No Space for Participation:

Pastoralist Narratives and the Etiology of Park-Herder Conflict in Southeastern Niger. Land Degradation and Development 10:345-363.

Weladji, Robert B., Stein R. Moe, and Pål Vedeld. 2003. Stakeholder Attitudes Towards Wildlife Policy and the Bénoué Wildlife Conservation Area, North Cameroon. Environmental Conservation 30:334-343

Wells, Michael P. and Thomas O. McShane. 2004. Integrating Protected Area Management with Local Needs and Aspirations. Ambio 33:513-519.

Zanetell, Brooke Ann and Barbara A. Knuth. 2002. Bribing Biodiversity: Corruption, Participation, and Community-Based Management in Venezuela. Southern Rural Sociology 18:130-161.

\section{Biosketches}

Jocelyn Müller is a PhD scientist in the biology department at Tufts University. She has been working and researching in Niger on the areas of conservation, ethnobotany and local ecological knowledge since 2001.

Iro Dan Guimbo is a teaching assistant and lecturer and $\mathrm{PhD}$ candidate in the agriculture and forestry department at the University of Abdou Moumouni in Niamey, Niger. A native of the Maradi region, Mr. Dan Guimbo has been working in the Boumba/Park W area since conducting his master's thesis in the area in 2006. 